\title{
Preliminary results on plasma progesterone levels during pregnancy and superfetation in the hare, Lepus europaeus
}

\author{
Monique Caillol and Lise Martinet \\ Station de Physiologie Animale, I.N.R.A., 78350 Jouy-en-Josas, France
}

\begin{abstract}
Summary. Peripheral plasma progesterone levels were studied in pregnant hares. A rise occurred at the beginning of pregnancy, followed by a plateau from Days 10 to 35 , and then a drop during the days just before parturition. No significant differences were noted between progesterone levels in pregnancies initiated at the pre-partum oestrus and those from other oestrous periods.
\end{abstract}

\section{Introduction}

Pregnancy lasts 41 days in the European hare, but the interval between two successive parturitions is often shorter, ranging between 35 and 40 days. According to Hediger (1948) and Martinet et al. (1970), this is due to conception occurring at a fertile oestrus some days before parturition. At least $60 \%$ of female hares are thought to experience a pre-partum oestrus. Two overlapping pregnancies resulting from two different ovulations give rise to fascinating endocrinological problems. In many species, including the rabbit, oestrus does not occur during pregnancy in the presence of progesterone. The present study was undertaken therefore to examine the levels of progesterone in hares during normal pregnancy and during pregnancy when superfetation occurs, and to correlate these levels with the pre-partum oestrus.

\section{Materials and Methods}

Hares born in captivity were kept in permanent pairs, one male and one female, throughout the year in large $2 \mathrm{~m}^{2}$ pens. Dry rabbit pellets, hay and water were freely available.

Oestrous behaviour was recorded by observation of sexual chases or matings during 140 pregnancies in 34 females.

For the histological study, 31 ovaries from 21 females at different stages of pregnancy were fixed in Holland's fixative, sectioned at $10 \mu \mathrm{m}$ and stained with haematoxylin and eosin. The size of the corpora lutea was calculated from the mean of the two largest diameters.

Plasma progesterone levels were determined for four females during the whole gestation period, two during normal pregnancy and two during pregnancy initiated at the pre-partum oestrus, and for two other females during pseudopregnancy. Hares were restrained in a small wooden box with suitably placed holes for the ears. Animals that were too nervous were discarded; the rest remained quiet and were bled without anaesthesia. The blood samples were withdrawn from the ear vein into a heparinized syringe and the plasma stored at $-20^{\circ} \mathrm{C}$ until assayed individually by radioimmunoassay.

After addition of $0.9 \mathrm{ml}$ phosphate buffer $(\mathrm{pH} 7.25)$ to $0.1 \mathrm{ml}$ plasma, extraction was performed with $10 \mathrm{ml}$ hexane at $20^{\circ} \mathrm{C}$. About $1000 \mathrm{ct} / \mathrm{min}$ of tritiated progesterone (sp. act. $82 \mathrm{Ci} / \mathrm{mmol}$; Radiochemical Centre, Amersham) was added to each plasma sample to measure extraction losses. To the evaporated extract, $1 \mathrm{ml}$ phosphate buffer was added; $0.5 \mathrm{ml}$ of this was used for calculation of the extraction losses and two samples of $0.1 \mathrm{ml}$ for assay. The radioimmunoassay was performed by adding $0 \cdot 1 \mathrm{ml}$ rabbit antiserum at a dilution of $1: 25,000$ and $0 \cdot 1 \mathrm{ml}$ tritiated progesterone (about $10,000 \mathrm{ct} / \mathrm{min}$ ) to the samples which were then incubated overnight at $4^{\circ} \mathrm{C}$. The antiserum was 
raised in rabbits immunized with 11-hemisuccinate progesterone conjugated to bovine serum albumin. It was highly specific, the cross-reaction obtained being only $2 \%$ with $5 \alpha$-pregnane-3,20dione. The separation of free and bound fractions was obtained by double precipitation with antirabbit gammaglobulin ovine serum.

\section{Results}

As shown in Table 1, sexual chases and matings were very often observed at the end of pregnancy, especially 3 to 5 days before parturition.

Table 1. The occurrence of mating before parturition in 140 pregnancies of hares

\begin{tabular}{llllllllllll}
\hline & \multicolumn{10}{c}{ Days before parturition } \\
\cline { 2 - 12 } & 10 & 9 & 8 & 7 & 6 & 5 & 4 & 3 & 2 & 1 & 0 \\
\hline Incidence of mating (\%) & 1 & 1 & 1 & 3 & 8 & 16 & 27 & 23 & 12 & 6 & 2 \\
\hline
\end{tabular}

The corpora lutea of the hare were found deep in the ovary. The mean diameter of the corpus luteum increased from $2 \mathrm{~mm}$ on Day 2 to $7 \mathrm{~mm}$ on Days 35 to 41 of gestation and regressed rapidly after parturition (Text-fig. 1). Small accessory corpora lutea were occasionally observed in some ovaries.

Basal progesterone levels were below $5 \mathrm{ng} / \mathrm{ml}$ in oestrous females. They increased from Day 2 to Day 15, then fluctuated widely, and began to decrease 2 or 3 days before parturition (Text-fig. 2a).

Although the concentration of progesterone at mating differed $(15 \mathrm{ng} / \mathrm{ml}$ and $65 \mathrm{ng} / \mathrm{ml})$ in the two animals studied throughout the course of pregnancy resulting from conception at a pre-partum

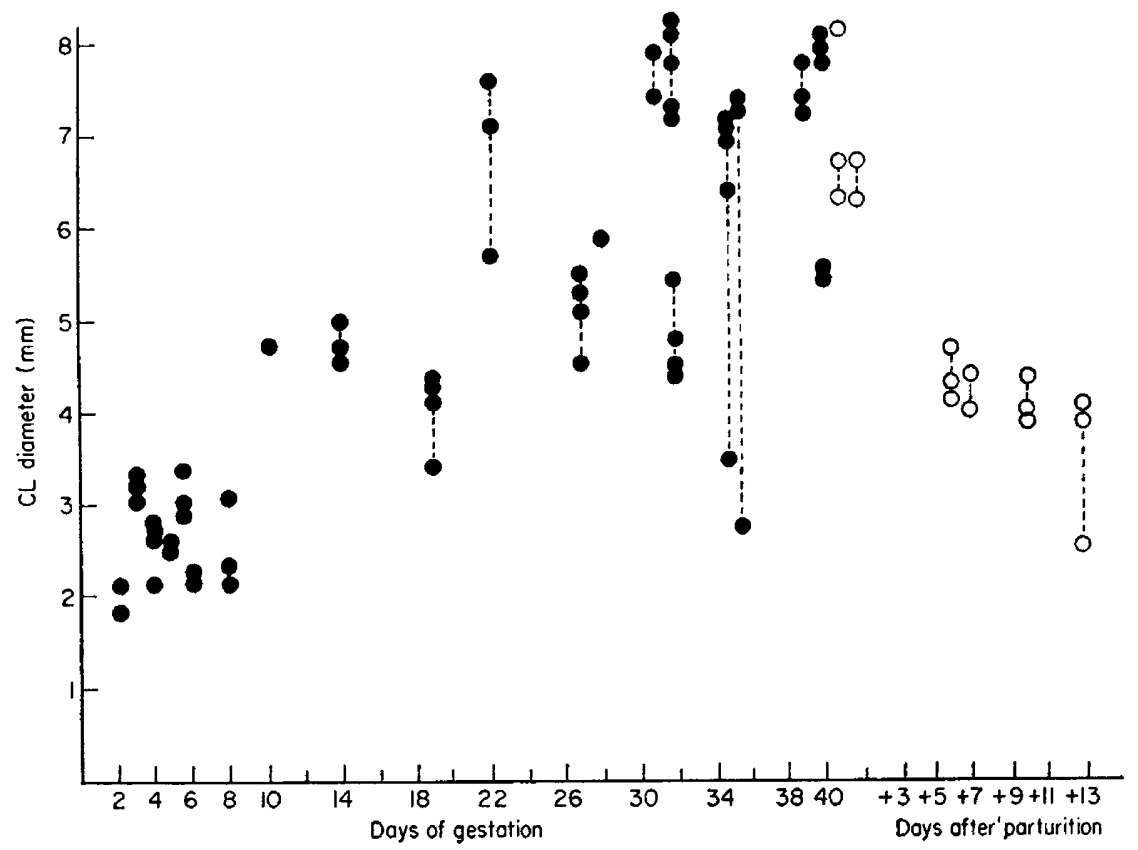

Text-fig. 1. Growth of the corpora lutea during pregnancy in the hare. $\bullet$, Before parturition; 0 , after parturition; ---, CL in the same female. 

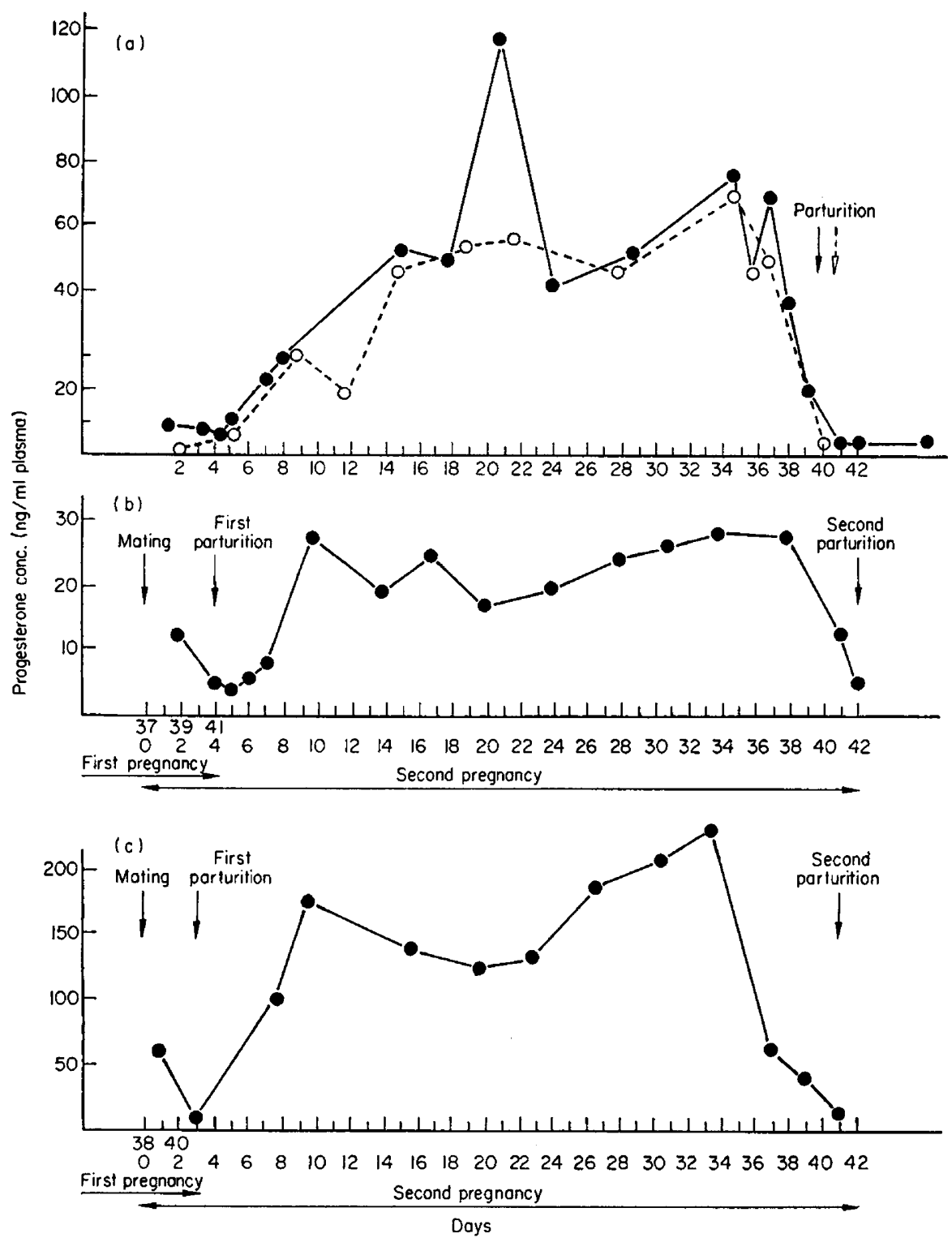

Text-fig. 2. Peripheral plasma progesterone levels in hares conceiving (a) at an oestrus other than the pre-partum oestrus, and $(b, c)$ at the pre-partum oestrus.

oestrus, the progesterone levels in both fell before the first parturition (Text-figs $2 b$ and $2 c$ ). Maximum levels occurred by Day 10 and were maintained until 4 and 3 days before the second parturition when they again fell.

The blood progesterone level during pseudopregnancy increased as at the onset of gestation and dropped suddenly on Day 14 or 15 after mating (Text-fig. 3).

\section{Discussion}

In the pregnant hare, plasma progesterone levels are mostly higher than those of 20 to $30 \mathrm{ng} / \mathrm{ml}$ reported for the rabbit (Challis et al., 1973), and may reach concentrations of $200 \mathrm{ng} / \mathrm{ml}$. The pro- 


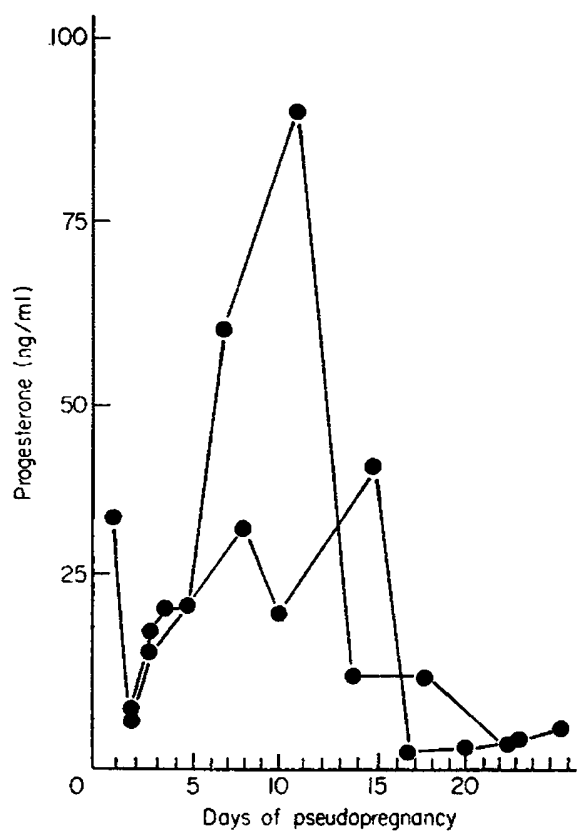

Text-fig. 3. The plasma progesterone levels during pseudopregnancy in two hares.

gesterone curves in the hare parallel the growth of the corpora lutea, which do not regress before parturition and probably constitute the main source of progesterone, although no data are available at the present time on the role of placenta in the maintenance of pregnancy in this species. The moment when progesterone began to decrease during the last part of pregnancy corresponded to the onset of oestrus.

A fall in the progesterone level may not be the only factor responsible for the appearance of oestrus, however, since oestrogens may also be required. The decrease of progesterone in the rabbit before parturition is not accompanied by an oestrogen surge (Challis et al., 1973), but Beyer \& Rivaud (1965) noted that oestrus may appear a few days before parturition in this species. The possible role of oestrogens and the interaction with progesterone in the pre-partum oestrus in the female hare remain to be evaluated.

We thank Dr F. Dray and M. Terqui for the antiprogesterone antibody.

\section{References}

Beyer, C. \& RIvaud, N. (1969) Sexual behavior in pregnant and lactating domestic rabbits. Physiol. Behav. 4, 753-757.

Challis, J.R.G., Davis, I.J. \& Ryan, R.J. (1973) The concentrations of progesterone, estrone and estradiol-17\% in the plasma of pregnant rabbits. Endocrinology 93, 971-976.
Hediger, H. (1949) Die Zucht des Feldhasen (Lepus europaeus Pallas) in Gefangenschaft. Physiol. comp. Oecol. 1, 46-62.

Martinet, L., Llegouis, J.J. \& Moret, B. (1970) Quelques observations sur la reproduction du lièvre (Lepus europaeus) en captivité. Annls Biol. anim. Biochim. Biophys. 10, 195-202. 